\title{
INSIGHTS TOWARDS CULTURAL ASPECTS AND RELATED IMPACTS OF LESSON STUDY PRACTICES: A SYSTEMATIC REVIEW
}

\author{
CARMEM SILVIA LIMA FLUMINHAN ${ }^{1}$ \\ ORCID: https://orcid.org/0000-0002-0342-2474 \\ ELISA TOMOE MORIYA SCHLÜNZEN ${ }^{2}$ \\ ORCID: https://orcid.org/0000-0003-1138-8541 \\ KLAUS SCHLÜNZEN JUNIOR ${ }^{3}$ \\ ORCID: https://orcid.org/0000-0002-5623-6093
}

\begin{abstract}
Lesson Study (LS) is a professional development model that Japanese teachers have been utilizing for over a century. Although several scholars have proclaimed the benefits of adopting LS in international educational systems, it is still unclear how LS has been used and how it should be implemented in cultures beyond Japan. In order to shed light on the theme, a Systematic Review was conducted aiming to (1) identify specific features of LS practices as they are developed in different settings, (2) verify and analyze what cultural aspects may have impacted the implementation of LS, and (3) verify and develop analysis of challenges for the use of successful practices of LS in international contexts. 5 international academic databases were searched in order to identify 28 publications. This investigation provides multiple evidences of the fast global spread of LS and reveals that some key adaptations or redesigns are conducted so that LS meets local needs and conditions. It argues that time constraint, financial support, search for quick results and inclusion of knowledgeable others are critical aspects that should be considered when introducing LS to a new context. Finally, this study suggests further avenues for research to deepen the understanding of how the LS movement should be properly implemented in different contexts outside Japan.
\end{abstract}

Keywords: Lesson Study, Professional Development, Teacher Education, Cultural Implications, Systematic Literature Review.

\section{ASPECTOS CULTURAIS E IMPACTOS RELACIONADOS ÀS PRÁTICAS DE LESSON STUDY: UMA REVISÃO SISTEMÁTICA}

RESUMO: Lesson Study (LS) é um modelo de desenvolvimento profissional utilizado há mais de um século por professores japoneses. Embora vários especialistas tenham proclamado os benefícios da adoção do LS em sistemas educacionais internacionais, ainda não está claro como o LS tem sido utilizado e como deveria ser implementado em culturas fora do Japão. Para aprofundar as discussões sobre o tema, foi realizada uma Revisão Sistemática com os objetivos de (1) identificar características específicas das práticas de LS desenvolvidas em diferentes contextos, (2) verificar e analisar quais aspectos culturais podem ter impactado a implementação de LS, e (3) verificar e analisar quais são os desafios apontados na literatura para o desenvolvimento de práticas exitosas de LS em contextos internacionais. 28 publicações foram identificadas para a análise em 5 bases de dados acadêmicas internacionais. Esta pesquisa revela várias evidências a respeito da rápida disseminação do LS em

\footnotetext{
${ }^{1}$ São Paulo State University. Presidente Prudente, São Paulo (SP), Brazil. <carmem.fluminhan@unesp.br>

${ }^{2}$ University of Western São Paulo. Presidente Prudente, São Paulo (SP), Brazil. <elisa.tomoe@unesp.br>

${ }^{3}$ São Paulo State University. Presidente Prudente, São Paulo (SP), Brazil. <klaus.junior@unesp.br>
} 
ambientes internacionais e aponta as principais adaptações ou redesenhos implementados ao modelo LS para que este atenda às necessidades e condições locais. Os dados demonstram que a restrição de tempo, o apoio financeiro, a busca por resultados rápidos e a inclusão de especialistas são aspectos críticos que devem ser considerados na introdução de LS em um novo contexto. Por fim, foram extraídas implicações educacionais bem como sugestões para futuras pesquisas para ampliar a compreensão de como o movimento LS deve ser implementado adequadamente em diferentes contextos fora do Japão.

Palavras-chave: Lesson Study, Desenvolvimento Profissional, Formação de Professores, Implicações Culturais, Revisão Sistemática da Literatura.

\section{ASPECTOS CULTURALES E IMPACTOS RELACIONADOS CON LAS PRÁCTICAS DEL ESTUDIO DE CLASES: UNA REVISIÓN SISTEMÁTICA}

RESÚMEN: Estudios de Clases (EC) es un modelo de desarrollo profesional utilizado durante más de un siglo por los profesores japoneses. Aunque varios expertos han proclamado los beneficios de adoptar EC en los sistemas educativos internacionales, aún no está claro cómo se ha utilizado EC y cómo debe implementarse en culturas fuera de Japón. Para profundizar las discusiones sobre el tema, se realizó una Revisión Sistemática con los objetivos de (1) identificar características específicas de las prácticas de EC desarrolladas en diferentes contextos, (2) verificar y analizar qué aspectos culturales pueden haber impactado la implementación de EC, y (3) verificar y analizar cuáles son los desafíos identificados en la literatura para el desarrollo de prácticas exitosas de EC en contextos internacionales. Se identificaron 28 publicaciones para su análisis en 5 bases de datos académicas internacionales. Esta investigación revela varias evidencias sobre la rápida difusión del EC en entornos internacionales y señala las principales adaptaciones o rediseños implementados al modelo LS para que responda a las necesidades y condiciones locales. Los datos demuestran que las limitaciones de tiempo, el apoyo económico, la búsqueda de resultados rápidos y la inclusión de especialistas son aspectos críticos que se deben considerar al introducir el EC en un nuevo contexto. Finalmente, se extrajeron implicaciones educativas, así como sugerencias para futuras investigaciones para ampliar la comprensión de cómo el movimiento de EC debería implementarse adecuadamente en diferentes contextos fuera de Japón.

Palabras clave: Estudio de Clases, Desarrollo Profesional, Capacitación de Profesores, Implicaciones Culturales, Revisión Sistemática de la Literatura.

\section{INTRODUCTION}

Lesson Study (LS) is claimed to be a process for developing and implementing effective classroom learning which favors innovation and promotes fast growing teacher professional development (DUDLEY et al., 2019). Lesson study is a form of collaborative and active research that is used for accomplishing pre-defined teaching and learning goals (TAKAHASHI; McDOUGAL, 2016) and continuous improvement of teaching practice (NORWICH, 2018). Through such an approach, teachers jointly study teaching contents and instructions by observing lessons and reflecting on them (STIGLER; HIEBERT, 2016).

Originated in Japan in the 1870's (DUDLEY, 2011), LS has been receiving a growing interest around the globe and, as a consequence, international influence (NORWICH, 2018). The World Association of Lesson Study (WALS) annual conference held online in December 2020 showed presentations from a variety of different countries embedded in various educational cultures, theoretical educational traditions and policy contexts. This trend is registered by Fang and Wang (2021), who verified that from 2007, WALS's first conference, to 2019, the number of countries represented by registered participants had increased from 15 to 43, across all the continents. As noted by Norwich 
(2018) and Lim-Ratnam et al. (2019), when introduced in a specific cultural setting, it is expected that the LS model will be adjusted to accommodate local needs and conditions. This might explain why when LS is examined, its origin is often related.

Jugyou kenkyuu, translated as Lesson Study, was first introduced outside Japan in the late 1990s (LEWIS, 2000; TAKAHASHI; McDOUGAL, 2016). It refers to a professional teacher development model that centers around a theme or goal (YOSHIDA, 1999) "of which the research lesson is the core piece" (LEWIS, 2000, p. 4). Further, Lewis, Perry and Murata (2006) explain that the term in Japanese indicates that LS is featured by the "observation of live classroom lessons by a group of teachers who collect data on teaching and learning and collaboratively analyze it" (p. 3). Although LS shares some characteristics with other professional development approaches, the authors underscore that this model has a unique set of characteristics that no other approach possesses and features a live classroom lesson as the heart of the process. In this respect, Cajkler et al. (2015) add that LS distinguishes from other forms of professional development as the planning of research lessons is designed jointly to address specific learning problems, "rather than focusing on the performance of an individual teacher" (p. 192).

Traditionally, Japanese LS occurs across many curriculum areas or themes (YOSHIDA, 1999) and is implemented in four phases: (1) study curriculum and formulate goals; (2) plan, which refers to selecting and revising the research lesson in detail; (3) teach, when one member of the team teaches the research lesson and the others observe and collect data; and (4) reflect on one's own practice and beliefs with a view to its improvement (LEWIS, 2002; LEWIS; PERRY; MURATA, 2006; DUDLEY et al., 2019). LS is conducted iteratively and may cycle in numerous times through the four phases, sometimes lasting years (FERNÁNDEZ, 2005), and research teams often meet two or three times per month for approximately 45 to 50 minutes, as in Saunders, Goldenberg and Gallimore (2009) or even weekly, as reported by Yoshida (1999) in his ethnographic research of the LS in math in a Japanese elementary school, and it is developed for traditionally one year long, as detailed by Fujii (2014).

In his guide on how to use LS "to develop and refine teaching, learning and teacher practice knowledge", Dudley (2011, p. 4) advices that the LS team should identify around three "case pupils' who will represent the wider group of learners in the class. These pupils will be observed and monitored as case studies representing the impact of LS on the larger group. The author suggests that a post research lesson discussion should be held not only to analyze how the 'case pupils' responded to the LS approach and how they developed learning during the process, but also to inform the team about the aspects that favored or hindered learning and how the team should overcome them in future classes.

According to Lewis, Perry and Hurd (2004), educators engaged in LS in Japan and the United States have acknowledged seven pathways that emerge from LS successful practice: "increased knowledge of subject matter, increased knowledge of instruction, increased ability to observe students, stronger collegial networks, stronger connection of daily practice to long-term goals, stronger motivation and sense of efficacy, and improved quality of available lesson plans" (p. 19). Although a growing number of scholars echoes LS benefits (e.g. YOSHIDA, 1999; LEWIS, 2000; SITGLER; HIEBERT, 2016; NORWICH, 2018; DUDLEY et al., 2019, ELLIOTT, 2019; VERMUNT et al., 2019, SCHIPPER et al., 2020), it is also recognized that this process cannot be simply transported worldwide. The main reason for this lies on the nature of "beliefs about teaching and educating teachers", which are intrinsically embedded "in a particular culture and particular organizational forms and career prospects" (YOSHIDA, p. 463, 1999). Additional support for this claim comes from Stigler and Hiebert (2016), who argue that "it is harder than we think to import a routine developed in one culture and in one educational system into countries with different cultures and different systems" (p. 581). In this sense, the effort of investigating and pointing out ways to implement LS practice in other parts of the world has emerged as crucial and critical.

\section{PURPOSE OF THIS PAPER AND RESEARCH QUESTIONS}

The objectives of this systematic review of lesson study practices were:

1. Identify the following features of the LS practices: 
i. Type of LS practice applied (specificities, phases included, knowledgeable others contributions)

ii. Purpose(s) for using LS

iii. LS team

iv. Professional development stage

v. School phase

vi. Curriculum area or theme involved

2.Verify and analyze cultural aspects that might influence the impacts of LS practices in different contexts

i. Identify where the study took place

ii. Exam aspects or variations applied to the conduction of LS due

to local conditions or cultural aspects

3. Identify limitations and develop analysis of challenges for the practice of Lesson Study in different contexts.

Accordingly, three research questions (RQ) were pursued in this paper:

RQ1. How has LS been implemented around the globe and what characteristics does it present?

RQ2. What cultural aspects or local conditions may have influenced LS outcomes?

RQ3. What lessons inform future researches or projects as to the necessary adaptations that should be made in order to develop a successful LS model?

\section{METHOD}

According to Moher et al. (2009, p. 1), "a systematic review is a review of a clearly formulated question that uses systematic and explicit methods to identify, select, and critically appraise relevant research, and to collect and analyse data from the studies that are included in the review." This definition is in accordance with the definitions reported in the PRISMA Statement and is in line with The Cochrane Collaboration (MOHER et al., 2015). Drawing from the guidance of Gough, Thomas and Oliver (2012) work to organize the data collection procedures, this systematic review of LS comprised the following stages: (i) developing and executing a search strategy; (ii) selecting studies from their titles and abstracts for detailed review; and (iii) analysis of full texts selected studies for eligibility. These stages are explored in the following.

This systematic review focuses on the academic research literature in peer-viewed journals written in the Portuguese, Spanish or English languages. It does not draw on professional practice papers, books, PhD dissertations and guides about Lesson Study. The search was undertaken in October and November, 2020, and the selected databases were chosen for being repositories of publications in the target languages of this systematic review. The electronic databases used in this study were: Educational Information and Resource Center (ERIC), Red Iberoamericana de Innovación y Conocimiento Científico (REDIB), ProQuest, Scientific Electronic Library Online (SciELO) and Emerald Insight.

\section{Selection of Studies for Detailed Review}

In order to review empirical research on Lesson Study across the globe, the authors conducted searches by title and abstract in the five academic databases aforementioned, and, in some cases, using different search terms, as detailed below. At this moment, three other articles were included from other sources. The complete screening process with database searches, the number of abstracts screened and the full texts retrieved or rejected, as well as exclusion criteria are shown in Figure 1.

The first database to be searched was ERIC and the search term was "lesson study" for all peer-viewed papers which made their full text available and with no definite time period. This searching led to a list of 3,376 papers. However, even though many of these contained the words "lesson" and "study" in the title or abstract, an expressive number proved not to relate to the Lesson Study approach, object of this article. Then, two distinct searches were conducted with the term "lesson study methodology" and, next, with the terms "Lesson Study" combined with "technology", again for all 
peer-viewed papers which made their full text available and with no definite time period. Combining through these two searches, a total of 294 articles were identified.

The next database to be consulted was REDIB. Two distinct searches were conducted using the following search terms: "metodología Estudios de Clase" combined with "educación" and then, another search using the terms "Lesson Study methodology" associated with "education". Both searches were limited to articles in scientific journals and Education and scientific Education materials with no time restriction. The total number of articles recovered was 210.

In the following, a search was carried out in the ProQuest database using the search terms "Lesson Study" AND "Education", limited to articles that were peer-reviewed with their full texts available. Due to the high number of publication identified (227,735), the search was narrowed. The second search was conducted using the search terms "Lesson Study" (in the title) AND "Education" AND "Culture". The search was limited to full-text articles available and peer-viewed articles between 2016 and 2020 published in English. The total of articles identified was 94.

Two distinct searches were conducted in the SciELO database. The search term "Metodologia Lesson Study" was used and no limited period of time nor language was set. Next, the search terms "Lesson Study" AND "Educação" were used. Combining both searches, a total of 48 articles were identified.

The search words "Lesson Study" (in the title) AND "Education" were used to conduct a search in Emerald Insight database for articles with full access. No definite time period limit nor language restriction was set. A total of 15 articles were identified.

From the databases consulted, 636 articles were identified for screening. One of the documents was not available online, two were straight duplications, and five hundred fifty-one publications were not related to Lesson Study practice. Hence, a total of five hundred fifty-four articles were excluded at this stage. In the following, the authors proceeded to a full text screening of the eighty-five remaining publications considered for eligibility.

\section{Selected Studies for Eligibility} criteria:

The selection of the studies for final inclusion and in-depth review involved the following

1. The publication had to be peer-reviewed research article (editorials, review of literature studies or commentaries of studies were excluded)

2. Study had to deploy Lesson Study empirical practice in the Educational context

3. The methods and/or analytical approaches were clear and described in detail

4. The study described at least one complete cycle of Lesson Study practice

To address the aims of this systematic review, and in addition to the four criteria indicated above, the authors did a full text screening of the eighty-five articles selected in the previous stage. As a result of this process, fifty-eight documents were excluded for the following reasons:

- 1 described the perception of students;

- 1 aimed at reporting recommendations from teachers

- 3 reported unclear study design

- 5 were editorials for a scientific journal

- 5 focused on a specific phase of Lesson Study

- 7 presented reviews of Lesson Study

- 16 aimed at reporting theoretical or analytical study

- 20 provided perceptions of teachers and school leaders

By this method, a total of twenty-eight articles met the criteria of this study and were included in the systematic review. 
Figure 1 - PRISMA flowchart of screening process with database searches, the number of abstracts screened and the full texts retrieved

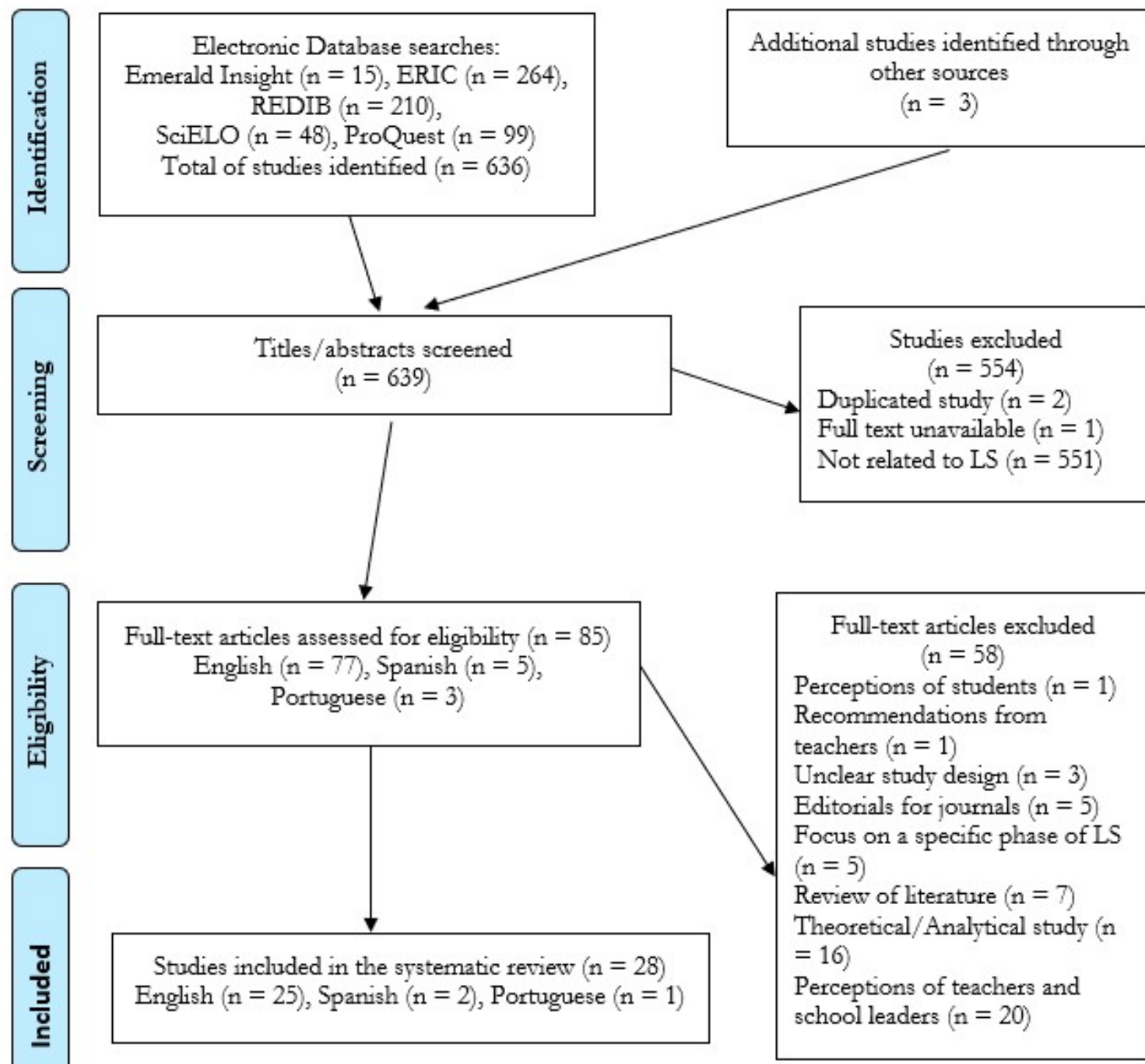

LS = Lesson Study

Source: The authors. Adapted according to the systematic analysis procedure proposed by Moher et al. (2015).

\section{KEY ISSUES IN THE PROCESS OF LESSON STUDY PRACTICE}

In order to reach the objective of this study, the 28 selected articles were analyzed in terms of the following areas:

1. Country where the studies were conducted

2. Curriculum area or theme involved

3. School phase

4. Study specificities (e.g. knowledgeable others contributions, use of revised research lesson, duration of the study and inclusion of students' perspective)

5. Professional development stage

6. Knowledge base (e.g. pedagogic practice and learning theory)

7. Purpose(s) for using Lesson Study 


\section{FINDINGS}

In order to answer the research questions, the data were analyzed and the aspects that emerged from the information gathered were established. The results of the research contain data on the following aspects: the country where the studies were conducted, the curriculum area involved, the school phase, specificities related to the team members and specific procedures adopted in the study, professional development stage (PDS) of participating teachers, the Knowledge base and the purpose(s) for using LS.

Data in Table 1 indicate that 15 countries are represented by publications on the selected model between 2012 and 2020. Most publications are concentrated in the United States (6) and the United Kingdom (4), followed by the Philippines (3) and Sweden (2). Austria, Canada, Chile, Ireland, Italy, Malaysia, Mexico, Portugal, Spain, Thailand and Turkey published one study each, and 2 studies did not specify the country where the research was developed.

Table 1 - Countries where the studies were conducted

\begin{tabular}{|c|c|c|c|}
\hline Country & Study & $n$ & f \\
\hline Austria & Klammer and Hansfstingl (2019) & 1 & 3.57 \\
\hline Canada & Zhou and $\mathrm{Xu}(2017)$ & 1 & 3.57 \\
\hline Chile & Ramos-Rodríguez, Matínez and Ponte (2017) & 1 & 3.57 \\
\hline Ireland & Shuilleabhain (2016) & 1 & 357 \\
\hline Italy & Bussi et al. (2017) & 1 & 3.57 \\
\hline Malaysia & Moon, Dali and Sam (2016) & 1 & 3.57 \\
\hline Mexico & Sánchez and Gómez-Blancarte (2015) & 1 & 3.57 \\
\hline Philippines & $\begin{array}{c}\text { Danday and Moterola (2019); Lomibao (2016); } \\
\text { Lucenario et al (2016) }\end{array}$ & 3 & 10.71 \\
\hline Portugal & Ponte et al. (2016) & 1 & 3.57 \\
\hline Spain & Calvo, Blanco and Fuevo (2018); & 1 & 3.57 \\
\hline Sweden & Klefbeck (2020), Leifler (2020) & 2 & 7.14 \\
\hline Thailand & Thinwiangthong, Eddy and Inprasitha (2020) & 1 & 3.57 \\
\hline Turker & Yemnez et al. (2017) & 1 & 3.57 \\
\hline $\begin{array}{l}\text { United } \\
\text { Kingdom }\end{array}$ & $\begin{array}{c}\text { Bradshaw and Hazzel (2016); Brown and Taylor (2016); } \\
\text { Griffiths (2016); Lamb (2015) }\end{array}$ & 4 & 14.28 \\
\hline $\begin{array}{l}\text { United } \\
\text { States }\end{array}$ & $\begin{array}{l}\text { Barber (2018); Hart (2009); Huang (2017); Lewis and } \\
\text { Perry (2014); Mostofo (2014); Soto et al (2019) }\end{array}$ & 6 & 21.42 \\
\hline $\begin{array}{l}\text { Not } \\
\text { specified }\end{array}$ & Suh and Fulginiti (2012); Yildiz and Baltaci (2017) & 2 & 7.14 \\
\hline Total & & 28 & 100 \\
\hline
\end{tabular}

$n=$ number of selected studies

$\mathrm{f}=$ frequency of selected studies

Source: The authors

The next data to be addressed is related to the curriculum area involved in the studies (Table 2). 19 of the 28 studies engaged in developing research involving Mathematics, being one of them with the objective of investigating strategies for teaching Mathematics for Special Educational Needs (SENs) students. English and Science were investigated in 3 studies each and Chemistry, Humanities, Physical Education and Physical Science were present in one study each. One study investigated the contributions of the LS approach for SENs environment across academic subjects. The total of publications indicated in Table 2 is 31 because some studies aimed to investigate more than one curriculum area or theme. Regarding the school phase (Table 3), 8 studies were conducted in high school, higher education was the setting of 7 studies, elementary and middle schools were involved in 5 studies each, 2 studies were in the context of graduate teacher training programs. 1 study did not specify the school phase in which the research was conducted. 
Table 2 - Curriculum area or theme involved

\begin{tabular}{lcc}
\hline Curriculum area & $\boldsymbol{n}$ & $\mathbf{f}$ \\
\hline Mathematics & 19 & 67.85 \\
\hline English (e.g. ESL and literacy) & 3 & 10.71 \\
\hline Science & 3 & 10.71 \\
\hline Special Educational Needs (SENs) & 2 & 7.14 \\
\hline Chemistry & 1 & 3.57 \\
\hline Humanities (e.g. geography, history, citizenship and social science) & 1 & 3.57 \\
\hline Physical Education & 1 & 3.57 \\
\hline Physical Science & 1 & 3.57 \\
\hline
\end{tabular}

$n=$ number of selected studies

$\mathrm{f}=$ frequency of selected studies

ESL $=$ English as a Second Language

Source: The authors

Table 3 - School phase

\begin{tabular}{lll}
\hline School phase & $\boldsymbol{n}$ & $\mathbf{f}$ \\
\hline Elementary school & 6 & 21.42 \\
\hline Middle School & 6 & 21.42 \\
\hline High School & 8 & 28.57 \\
\hline Higher Education & 7 & 25.00 \\
\hline Graduate Education & 2 & 7.14 \\
\hline Not Specified & 1 & 3.57 \\
\hline
\end{tabular}

$n=$ number of selected studies

$\mathrm{f}=$ frequency of selected studies

Source: The authors

Regarding the professional development stage (PDS) of the participating teachers (Table 4), the findings demonstrate that LS is mainly used in the context of continuing professional development $(\mathrm{n}=22)$, whereas it was much less required for educating pre-service teachers in higher education settings $(n=6)$.

Table 4. Professional development stage (PDS)

\begin{tabular}{lcc}
\multicolumn{1}{c}{ PDS } & $\boldsymbol{n}$ & $\mathbf{f}$ \\
\hline Pre-service & 6 & 21.43 \\
\hline Continuing Professional Development & 22 & 78.57 \\
\hline Total & 28 & 100 \\
$n=$ number of selected studies & & \\
f $=$ frequency of selected studies & & \\
Source: The authors & &
\end{tabular}

Table 5 summarizes the main findings revealed in the studies regarding the focus of enquiry, the team members involved, whether the study included the participation of knowledgeable others, whether participating teachers had previous experience in LS activities, the inclusion or not of students' perceived outcomes, the number of educational institutions engaged in the process, the duration of the study and whether a revised lesson was implemented. 


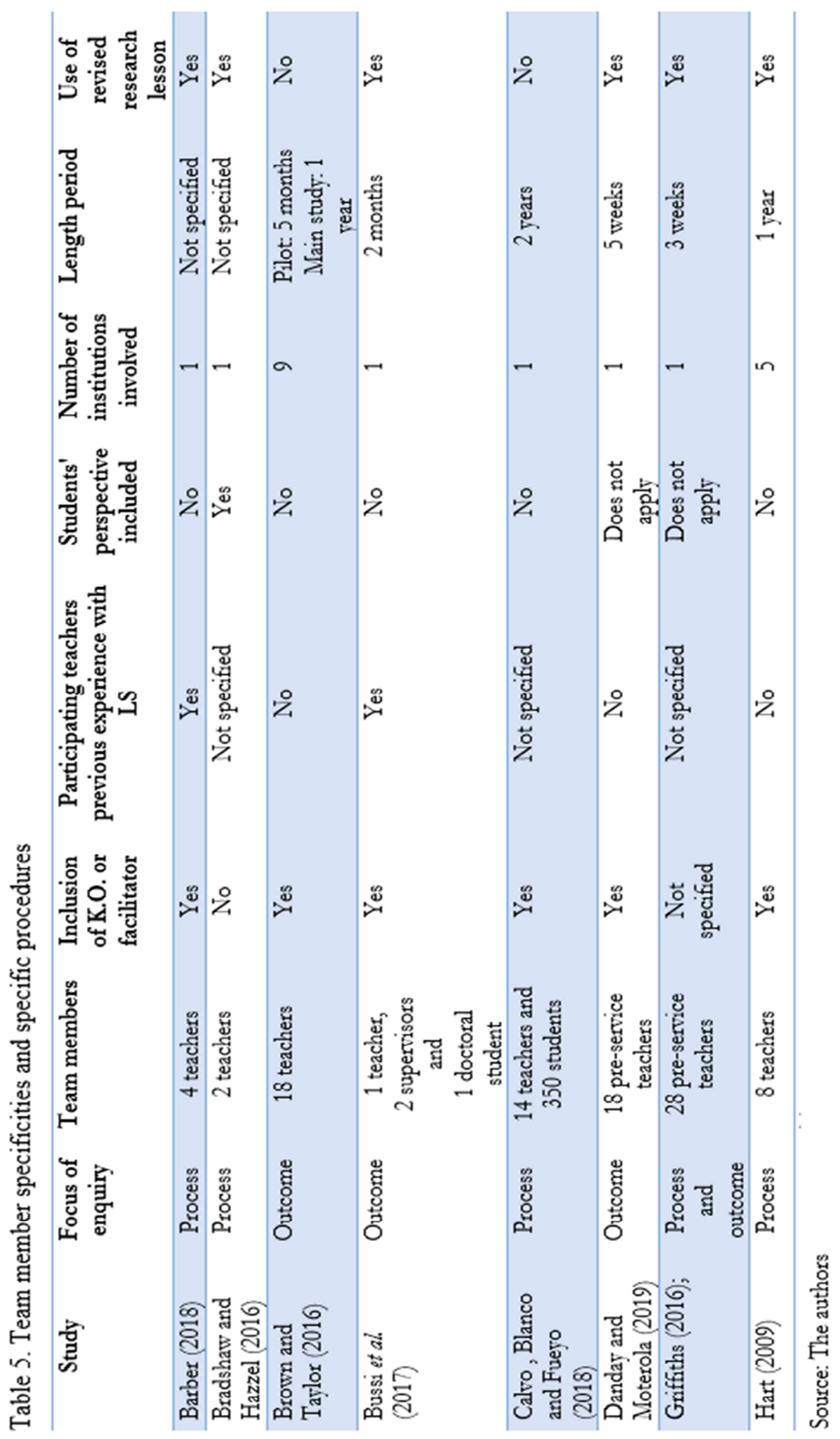




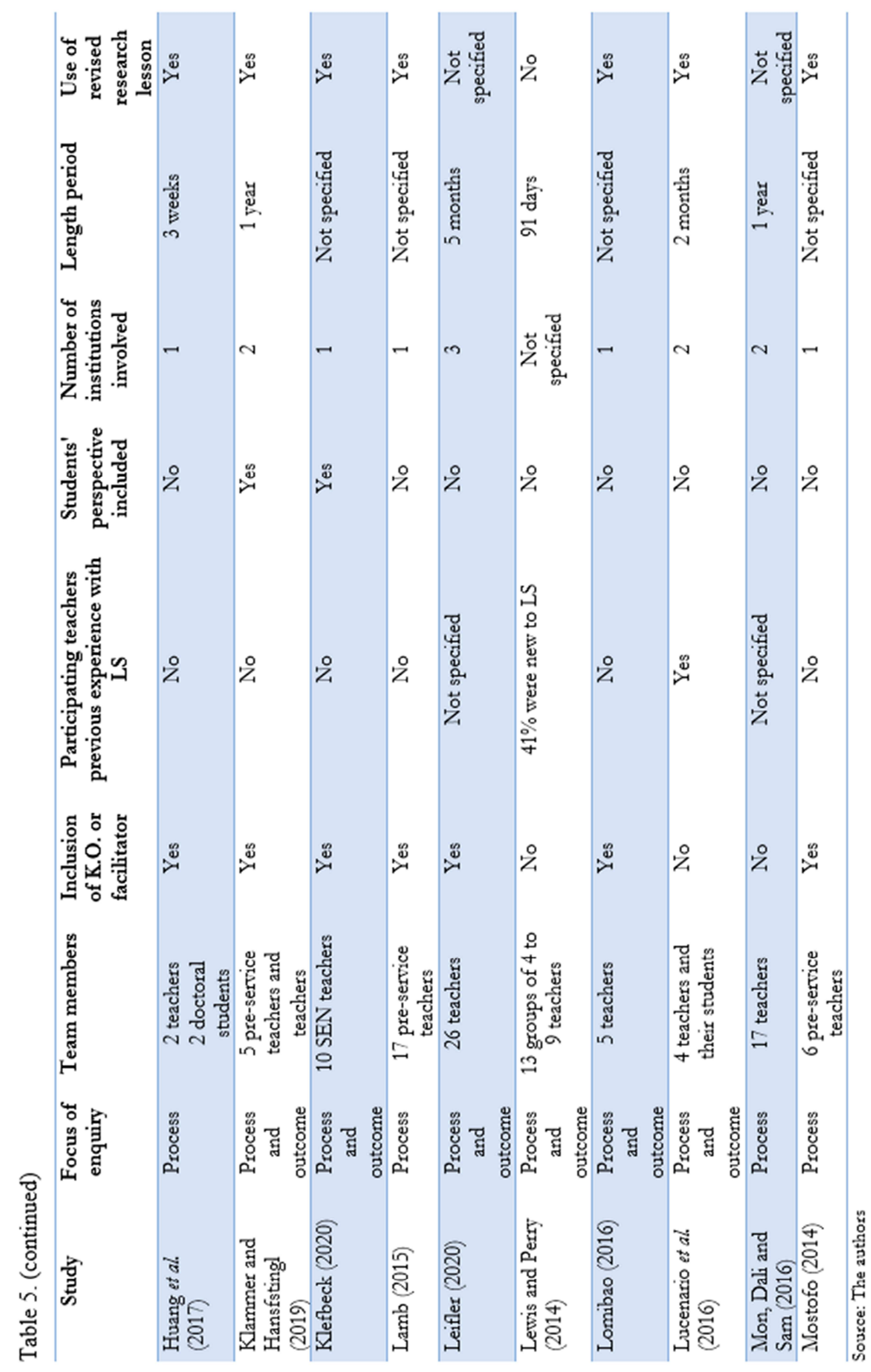




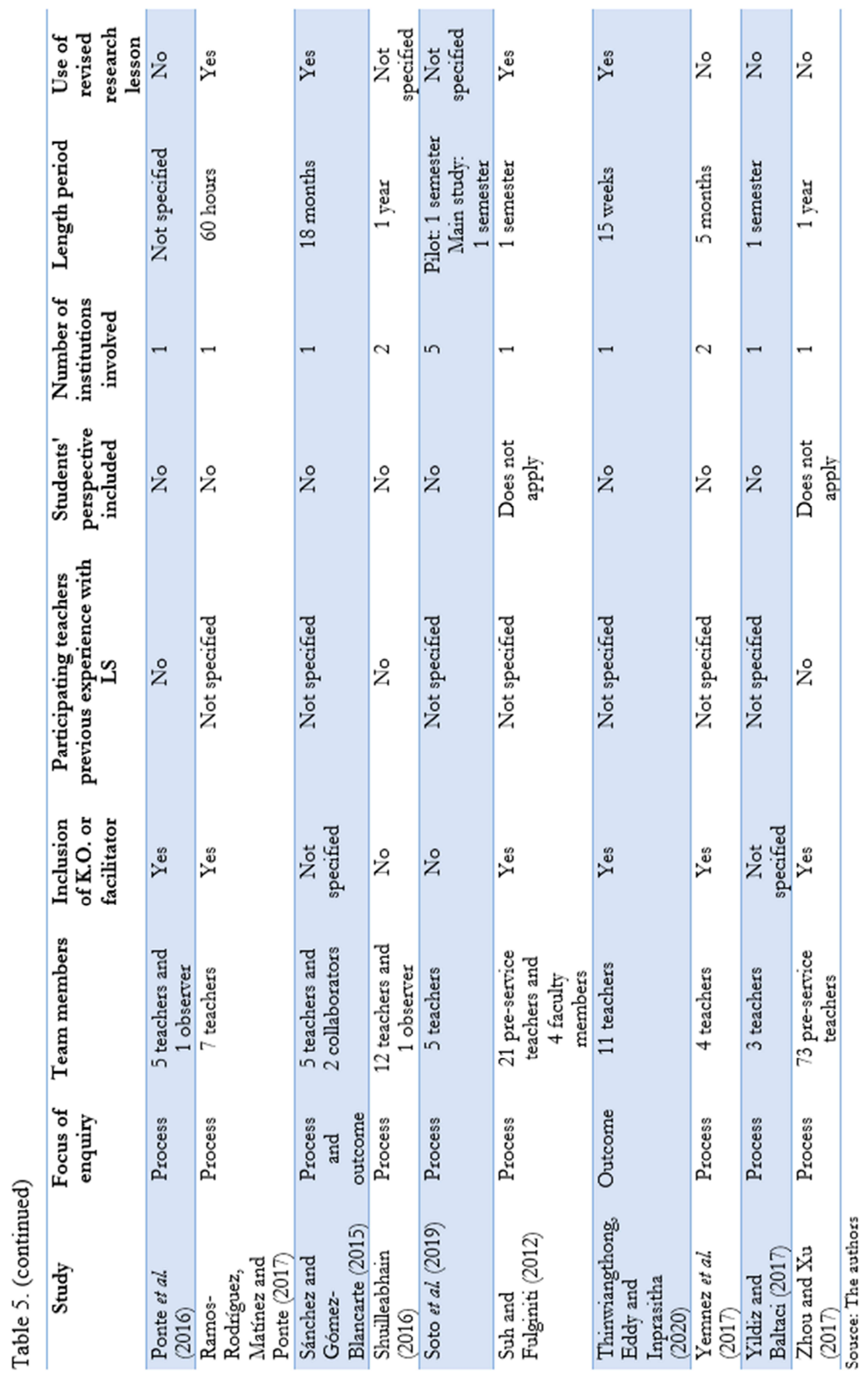


Table 6 lists six types of pedagogical practices and 23 learning theories or educational models integrated to LS indicated in the selected publications upon which the researches were built. 3 studies (HART, 2009; LEIFLER, 2020; LEWIS; PERRY, 2014) informed to have used LS approach alone to carry out the research.

Table 6 - Knowledge base integrated to LS practice

\section{Pedagogical practice}

\section{n $\quad$ f}

310.71 Calvo, Blanco and Fueyo (2018), Klammer and Hanfstingl (2019), Lamb (2015)

\begin{tabular}{lccl}
\hline Action research & 3 & 10.71 & $\begin{array}{l}\text { Calvo, Blanco and Fueyo (2018), Klammer and Hanfstingl } \\
(2019), \text { Lamb (2015) }\end{array}$ \\
\hline Co-teaching & 1 & 3,57 & Suh and Fulginiti (2012) \\
\hline $\begin{array}{l}\text { Professional learning } \\
\text { community }\end{array}$ & 7 & 25 & $\begin{array}{l}\text { Huang, Prince, Barlow and Schmidt (2017), Klammer and } \\
\text { Hanfstingl (2019), Leifler (2020), Lewis and Perry (2014), } \\
\text { Shuilleabhain (2016), Sánchez and Gómez-Blancarte (2015), } \\
\text { Soto et al. (2019), }\end{array}$ \\
\hline
\end{tabular}

Professional collaborative $\quad 14 \quad 50 \quad$ Barber (2018), Brown and Taylor (2026), Bussi, Bertolini and practice

Ramploud (2017), Calvo, Blanco and Fueyo (2018), Hart (2009), Huang, Prince, Barlow and Schmidt (2017), Klefbeck (2020), Lomibao (2016), Lucenario et al. (2016), Mon, Dali and Sam (2016), Ramos-Rodríguez, Martínez and Ponte (2011), Thinwiangthong, Eddy and Imprasitha (2020), Yenmez et al. (2017), Yildiz and Baltaci (2017)

\begin{tabular}{|c|c|c|c|}
\hline Problem solving group & 1 & 3,57 & Bradshaw and Hazell (2016) \\
\hline Teacher coaching & 4 & 14.28 & $\begin{array}{l}\text { Danday and Monterola (2019), Griffiths (2016), Mostofo } \\
\text { (2011), Yildizz and Xu (2017) }\end{array}$ \\
\hline Learning theory or model & $\mathrm{n}$ & $\mathrm{f}$ & Example \\
\hline $\begin{array}{l}\text { Model of Instructional } \\
\text { Improvement (Lewis et al., }\end{array}$ & 1 & 3,57 & Barber (2018) \\
\hline
\end{tabular}

$$
\text { 2002) }
$$

\begin{tabular}{llll}
$\begin{array}{l}\text { Interconnected Model of } \\
\text { Professional Growth } \\
\text { (Clarke, \& Hollingsworth, }\end{array}$ & 1 & 3,57 & Barber (2018) \\
2002) & & & \\
\hline \begin{tabular}{l} 
Process Model (Stenhouse, \\
\hline
\end{tabular} & 1 & 3,57 & Bradshaw and Hazell (2016)
\end{tabular}
1975)

\begin{tabular}{lccl}
\hline $\begin{array}{l}\text { Design Based Research } \\
\text { (Penuel } \text { et al., 2011 and } \\
\text { others) }\end{array}$ & 1 & 3,57 & Brown and Taylor (2026) \\
\hline $\begin{array}{l}\text { Student Voice "movement" } \\
\text { (Wood, \& Cajkler, 2016) }\end{array}$ & 1 & 3,57 & Calvo, Blanco and Fueyo (2018) \\
$\begin{array}{l}\text { Theory of Semiotic } \\
\begin{array}{l}\text { Mediation - TSM (Bartolini } \\
\text { Bussi, Mariotti, 2008) }\end{array}\end{array}$ & 1 & 3,57 & Bussi, Bertolini and Ramploud (2017) \\
\hline $\begin{array}{l}\text { Microteaching Multiple- } \\
\text { Representation Lesson } \\
\text { Study - MRLS }\end{array}$ & 1 & 3,57 & Danday and Monterola (2019) \\
\hline $\begin{array}{l}\text { Microteaching Lesson Study } \\
\text { - MLS }\end{array}$ & 1 & 3,57 & Zhou and Xu (2019) \\
\hline $\begin{array}{l}\text { Peer Microteaching Lesson } \\
\text { Study (PMLS) }\end{array}$ & 1 & 3,57 & Griffiths (2016) \\
\hline $\begin{array}{l}\text { Deliberate Practice } \\
\text { (Ericsson } \text { et al., 1993) }\end{array}$ & 1 & 3,57 & Huang, Prince, Barlow and Schmidt (2017) \\
\hline $\begin{array}{l}\text { Phases of Concern Model } \\
\text { Phas }\end{array}$ & 1 & 3,57 & Lamb (2015) \\
\hline
\end{tabular}

Source: The authors 
Table $6 \cdot$ (continued)
Pedagogical practice
n
f
Example

\begin{tabular}{|c|c|c|c|}
\hline $\begin{array}{l}\text { Technological Pedagogical } \\
\text { Content Knowledge - } \\
\text { TPACK (Bos, 2011) }\end{array}$ & 1 & 3,57 & Yildiz and Baltaci (2017) \\
\hline $\begin{array}{l}\text { Variation Theory (Lo, } 2012 \\
\text { and others) }\end{array}$ & 2 & 7.14 & Klammer and Hanfstingl (2019), Klefbeck (2020) \\
\hline $\begin{array}{l}\text { Phases of Concern Model } \\
\text { (Fuller, 1969) }\end{array}$ & 1 & 3,57 & Lamb (2015) \\
\hline $\begin{array}{l}\text { Reflection in Action and } \\
\text { Reflection on Action } \\
\text { (Schon, 1983) }\end{array}$ & 1 & 3,57 & Lomibao (2016) \\
\hline $\begin{array}{l}\text { Pedagogical Content } \\
\text { Knowledge (PCK) (Hill et } \\
\text { al., 2004) }\end{array}$ & 1 & 3,57 & Lucenario et al. (2016) \\
\hline $\begin{array}{l}\text { ALaCT Reflexive Process } \\
\text { (Korthagen, 2011) }\end{array}$ & 1 & 3,57 & Ramos-Rodríguez, Martínez and Ponte (2011) \\
\hline $\begin{array}{l}\text { Community of Practice - } \\
\text { CoP (Wenger, 2001, } \\
\text { Wenger, McDermott, \& } \\
\text { Snyder, 2002) }\end{array}$ & 2 & 7.14 & Sánchez and Gómez-Blancarte (2015), Soto et al. (2019) \\
\hline $\begin{array}{l}\text { Mathematical Knowledge } \\
\text { for Teaching - MKT (Ball, } \\
\text { 2003, Ball et al., 2016) }\end{array}$ & 2 & 7.14 & Suh and Fulginiti (2012), Shuilleabhain (2016) \\
\hline $\begin{array}{l}\text { Open Approach - OA } \\
\text { (Nohda, 2000) }\end{array}$ & 1 & 3,57 & Thinwiangthong, Eddy and Imprasitha (2020) \\
\hline $\begin{array}{l}\text { Mathematical Modeling } \\
\text { (Lingefjard, 2002) }\end{array}$ & 1 & 3,57 & Yenmez et al. (2017) \\
\hline $\begin{array}{l}\text { Technology-facilitated } \\
\text { Lesson Study }\end{array}$ & 1 & 3,57 & Soto et al. (2019) \\
\hline $\begin{array}{l}\text { Vygotsky Space (Galluci et } \\
\text { al., 2010) }\end{array}$ & 1 & 3,57 & Mostofo (2014) \\
\hline
\end{tabular}

Source: The authors

Table 7 lists the purposes for using LS as referred to in the examined studies. It is noted that, in some cases, the same study pointed out more than one purpose, what makes the LS purposes listed below outnumber the publications selected for this review. The findings show that the primary use of LS was to support teacher professional development $(n=29)$ aiming to promote those professionals' motivation, knowledge and skills. As far as student learning $(n=5)$ and the examination of teaching material $(n=1)$ are concerned, fewer studies pointed those purposes as the reasons for using the LS approach.

Table 7 - Lesson Study (LS) Purpose

\begin{tabular}{llcc}
\hline Purpose for using LS & & $\boldsymbol{n}$ & $\mathbf{f}$ \\
\hline \multirow{2}{*}{ Teacher Professional Development } & knowledge & 16 & 59.25 \\
\cline { 2 - 4 } & & 12 & 44.44 \\
\cline { 2 - 4 } & skills & 1 & 3.70 \\
\cline { 2 - 4 } & motivation & 5 & 18.51 \\
\hline Student Learning & & 1 & 3.70 \\
\hline Teaching Material Examination & & & \\
$\begin{array}{l}n=\text { number of selected studies } \\
\text { f }=\text { frequency of selected studies } \\
\text { Source: The authors }\end{array}$ & & & \\
\end{tabular}




\section{DICUSSION}

The growing international interest of LS in educational systems beyond Japan observed in the past few decades indicates that this model may be beneficial if appropriately implemented in foreign contexts. However, several professional experts have warned that simply enacting a LS routine to a new setting will not guarantee its efficiency (STIGLER; HIEBERT, 2016), rather, by missing the point of incorporating its core characteristics, chances are that LS will become one more perishable fad intended to promote progress towards pedagogical/learning science (LEWIS; PERRY; HURD, 2004). In order to contribute to the theme, this paper sought to (1) identify specific features of LS practices implemented in different contexts, (2) verify and analyze what cultural aspects may have impacted the implementation of LS, and (3) verify and develop analysis of challenges for the use of successful practices of LS in international settings.

The first question to be addressed is:

\section{RQ1. How Has LS Been Implemented Around the Globe and What Characteristics Does it Present?}

Since LS was brought to public attention in late 1990's (LEWIS; PERRY; MURATA, 2006; GROVES; DOIG, 2010; TAKAHASHI; McDOUGAL, 2016), this approach has reached various countries and all continents, such as Asia, Africa (FUJII, 2014), Europe, in particular (DUDLEY et al., 2019), and it has been increasingly investigated in the United States (LEWIS; PERRY; HURD, 2004). In his editorial review article, Elliott (2016) acknowledges the International Journal for Lesson and Learning Studies for having published a rich resource of material involving the European, Asian and North American contexts in various educational levels and across different school subjects and theories. This is consistent with the findings in this study that reveal that these regions alone concentrate more than $82 \%$ of the studies investigated, with a special remark to South America, where only one country was reported to having carried out one research, Chile.

Being the only country representing South America in this review, it is noted that the connection between Chile and LS did not happen unexpectedly. The implementation of LS in that country is the result of a program established between Chile and Japan, funded by JICA (Japan International Cooperation Agency), during three years (2006 to 2008) in which a total of three groups of 10 mathematics teachers belonging to eleven universities involved in initial and continuing training of teachers, and two members of the Ministry of Education participated in intensive courses in Japan for training in Japanese methodologies of LS (RAMOS-RODRÍGUEZ; MARTÍNEZ; PONTE, 2017; OLFOS; ISODA; ESTRELLA, 2020).

After 15 years of the initial investment in the educational system in Chile, and despite having faced political interference from the government in the past, today the country has maintained the LS approach nationwide, its researchers have spread it by publishing books and through participation in congresses in Latin America, and during ten years, LS has been the theme of a doctoral program in the country. Olfos, Isoda and Estrella (2020) confirm that meaningful improvements in the ongoing professional development was observed by teachers from Chile who participated in training programs and implemented the LS model in their local institutions.

Several supports are essential if LS is to be introduced and sustained in a new country. In fact, LS has been introduced in most countries through the support of funding from the government or research agencies (FANG; WANG, 2021). Therefore, it is critical that the administration at local, regional and national levels should share their responsibilities in order to provide time and financial support "to enable teachers to collaboratively plan, teach, collect evidence, and revise lessons" (STIGLER; HIEBERT, 2016, p. 585). Lack of shared time, workload and rigid schedules are some of the constraints identified in this review that could result in weak collaboration between the LS team members and, consequently, follow poorer results (see, for example, HART, 2009; MON; DALI; SAM, 2016; ALAMRI, 2020).

Although the goal of traditional Konaikenshu (school-based teacher training program), of which LS is a masterpiece, does not "exclusively focus on the development of students' academic 
skills" (YOSHIDA, 1999, p. 52) all the articles selected for this study pursued their goal in the context of investigating specific subject matters. Of the 28 identified articles, 19 (67.85\%) aimed to implement LS involving mathematics. In fact, this is in line with what is observed in other recent international reviews, in which researches referring to mathematics far outnumber the publications when compared to other school subjects (e.g. BAUMFIELD et al., under review; KANELLOPOULOU; DARRA, 2019). This finding could be attributed to the fact that LS was introduced in the west through research involving mathematics presented at the Third International Mathematics and Science Study in 1999 in the United States (LEWIS; PERRY; MURATA, 2006; GROVE; DOIG, 2010) in addition to the fact that American students presented low performance in the Trends in International Mathematics and Science Study (SAITO, 2012). These facts generated subsequent interest in addressing this problem. Similarly, LS was introduced in Chile through the agreement established in the collaboration program "Improving mathematical education in Chile supported by Japan" in 2005 (OLFOS; ISODA; ESTRELLA, 2020). As LS could be recognized as an "organic system" (FUJII, 2014) in which all teachers should work collaboratively driven by the same general purpose (STIGLER; HIEBERT, 2016), it is crucial that all school subjects are involved and specifically investigated through the LS approach so that it would produce more significant and sustained results. In compliance with Yoshida (1999), we argue that the impact of scant and isolated groups of teachers on students' learning is limited.

LS is acknowledged for being a powerful professional development model that can foster teacher learning by bringing teaching close to practice (NORWICH, not identified, SUH; FULGINITI, 2012; KOTELAWALA, 2012; CAJKLER et al., 2013, DUDLEY et al., 2019). However, it seems that traditionally, in Japan, most elementary and middle schools take part in LS, being less frequent in Japanese high schools (GROVES; DOIG, 2010) and in higher education. In this same direction, data in this study reveal that most researches, 12 of the $28(42.85 \%)$, took place in elementary and middle school settings, while it was less investigated in the undergraduate level $(25 \%)$. In line with this, another finding points out that LS was examined in the context of initial teacher education in only $21.43 \%$ of the studies, in contrast with in-service settings $(78.57 \%)$.

The literature confirms that, successfully integrated, LS is central for prospective teacher learning (FERNÁNDEZ, 2010; CAJKLER et al., 2013; SOTO et al., 2019) as it "encourages team members to bridge the gap between theory and practice" (SCHIPPER et al., 2020, p. 362). For example, Suh and Fulginiti (2012) discussed the challenge of providing the opportunity for preservice teachers to experience the complexity of teaching and, at the same time, for experienced teachers to plan lessons along with novice teachers situated in practice. This positive experience allowed pre-service teachers a safe and authentic environment to lessen their anxiety, develop specific pedagogical knowledge and reflect on their practice.

Correspondingly, Danday and Monterola (2019), reported that an experimental group of pre-service teachers benefited from experiencing microteaching multiple-representation LS and demonstrated better effects on the enhancement of critical thinking. Both studies concluded that feedback from experts, collaboration among fellow pre-service teachers and students, and length of preparation and of teaching influenced the positive results perceived. Therefore, we argue that LS is a prominent vehicle that should be introduced to teacher candidates beyond their preparation program to instill on them the lifelong commitment to reflective and collaborative practice necessary for their own engagement to professional development.

In terms of the specific procedures and characteristics implemented to the LS model, 16 studies $(57.14 \%)$ focused their evaluation on the process of LS, 8 studies $(28.57 \%)$ focused on both the process and the outcome, 4 studies (14.29\%) focused only on the outcome and 4 studies $(14.29 \%)$ did not specify this aspect. This finding may be explained by the fact that the literature unanimously views LS as a complex process that focuses on student, teacher and organizational learning (e.g. FUJII, 2014; STIGLER; HIEBERT, 2016; DUDLEY et al., 2019), and much more than the "final product", what matters is the process. This result might be connected with the controversial inclusion of teaching a revised lesson in the LS cycle. 
In this review, 17 studies $(60.71 \%)$ reported to having refined and re-taught a research lesson, 7 studies (25\%) did not use this resource and 4 studies $(14.29 \%)$ did not specify it. Some experts are emphatic saying that teaching a revised lesson is not a common practice in LS procedures in Japan (YOSHIDA, 1999; STIGLER; HIEBERT, 2016). Such a strategy is even 'disrespectful', as Fujii (2014) highlights, not only because a research lesson is unique and designed to a particular group of students, but also because students deserve the best and cannot be treated as scientific experiments. LS cannot be reduced to a means of producing more polished lessons (LEWIS, 2009), since it is much more than the lesson itself (LEWIS et al., 2006). Rather, trying to obtain a perfect lesson is to deviate from its main purpose (TAKAHASHI; McDOUGAL, 2016; ELLIOTT, 2019). Nevertheless, the overwhelming support for a high number of researches conducting a revised lesson in this review comes from adaptions adopted in settings outside Japan. Chinese Lesson Study, for example, requires repeating the revised research lesson (Huang, Prince, Barlow, \& Schmidt, 2017), and in the west, Dudley $(2011,2013)$ advocates it is part of the LS cycle, whereas Lewis (2009) considers it optional. As Stigler and Hiebert (2016) explain, reteaching a lesson might be of crucial importance in contexts outside Japan because it unveils hidden aspects that are taken for granted in that country, but needed to be demonstrated elsewhere.

Regarding the inclusion of facilitators or knowledgeable others, 19 of the selected studies $(67,86 \%)$ reported to have had such a professional during the process of implementing LS, 6 studies $(21.43 \%)$ did not include this professional, and $3(10.71 \%)$ did not specify this information. As for the team members, 12 studies $(42.86 \%)$ indicated that the professionals involved in the LS model did not have any experience with such an approach before, and the same number of studies did not specify it. As discussed in Bocala (2015), both novices and experts should work together in teacher learning models, since more experienced teachers, and knowledgeable others can encourage and give support to novice participants and provide essential expertise to the whole process. Knowledgeable others have been defined as someone, usually outside of the planning team, who play an important role in contributing during the planning process and the post-lesson discussion (DUDLEY, 2014; FUJII, 2016; TAKAHASHI; McDOUGAL, 2016).

According to Takahashi (2014, p. 10), knowledgeable others are responsible for "(1) bringing new knowledge from research and the curriculum; (2) showing the connection between the theory and the practice; and (3) helping others learn how to reflect on teaching and learning." In this respect, Yoshida (1999) informed that all the surveyed schools reported in his ethnographic study in Japan included an outside of school adviser as part of their organizational chart. In fact, especially in countries where LS is still not embedded in their culture, these professionals are considered of high relevance (SEINO; FOSTER, 2020), for "without them, knowledge and skills would remain empty concepts devoid of real application and use" (MEWALD; MÜRWALD-SHEIFINGER, 2019, p. 229).

Being often acknowledged as a "teacher-led" collaborative research designed to develop teaching (LEWIS, 2002; TAMURA; UESUGI, 2020), LS is mostly embedded in teachers' cultural perspective. This may explain why much less attention has been given to how students engage, perceive and experience their own learning. In the same vein, the results in this investigation indicated that only 3 studies $(10,71 \%)$ demonstrated to have investigated the learners' perspective, in contrast with 21 studies $(75 \%)$ that looked at the teachers' perceptions alone, and 4 studies $(14.29 \%)$ that did not make this formation explicit.

In this respect, Wood and Cajkler (2016) argue that when learning challenges and approaches to learning are identified only through the teachers' perspective, potential barriers still remain between teachers and students. The authors found that listening to their students' perceptions on what was difficult in the lesson and what they would change about it reflect on their own learning outcomes. This finding led the authors to propose a participatory approach to LS as a vehicle to provide new insights to the complex nature and process of learning involving the students. In the study conducted by Khokhotva and Albizuri (2020), teachers are also informed on how and what students need to learn through the voice of students, which brings significant implications to teachers' transformative learning, educational beliefs change and improvements in the lesson design. 
These studies provide new perspectives on having students participating in the LS process and reveal that significant impacts are recognized due to the students' active involvement.

Concerning the duration of the LS process indicated by the selected articles, the investigations occurred from three weeks to as far as 18 months, in an average of 1.8 institutions $(\mathrm{SD}=1.81)$. In contrast with cultures hungry for immediate results aiming at overnight improvements in test score (CAJKLER et al., 2015), LS is practiced with a view on long-term results in Japan. In Yoshida's account (1999), for example, the average length of School-Based Teacher Development focusing the same topic was about four years. Takahashi and McDougal (2016) warned about the decision of a school district of organizing the complete LS cycle on one single day and brought questions to whether this model could still be considered LS. As mentioned before, Lewis, Perry and Hurd (2004) pointed out that LS favors stronger connection between daily practice to the long-term goals pursued simultaneously by the teachers. Although scholars vary in developing researches in a different range of time length, what is unanimously agreed is that LS has the high potential to produce long-term impact on teachers practice and substantial positive outcomes on their students' academic success if sustained appropriately.

Among the pedagogical practices identified in the selected publications, professional collaborative practice is the one most used by the investigators $(50 \%)$. More variation was identified concerning the learning or teaching theory associated with LS practices. Of the 28 articles, 23 different related theories were identified. This might be due to the fact that LS is a flexible approach with room to be shaped according to cultural and organizational settings in order to meet the needs of teachers and students effectively (SCHIPPER et al., 2020).

Such a flexible model, led Wood (2020) to discuss the dimension of variation concerning the theories described by articles recently published in the International Journal for Lesson and Learning Studies. She underscored the importance of a research instruction "being explicit about the theory of learning informing lesson and learning studies and how its implementation leads to teacher learning" (Wood, 2020, p. 93) and raised the question about which theory is the one to underpin Japanese LS. The concern with theoretical approaches associated with LS had already been discussed by Norwich (2018). The author examined variations within LS practices and their connections with related professional learning and teaching traditions. Norwich concluded that the wide variation of practices identified in his investigation make it difficult to establish which features are necessary and sufficient "to distinguish LS practices from the other non-LS professional learning practices" (Norwich, 2018, p. 213) and suggested that a polythetic type of definition of professional learning and development practices might be useful to protect labels from being excessively used and deviated from its proper use.

\section{RQ. What Cultural Aspects or Local Conditions May Have Influenced LS Outcomes?}

The success credited to LS in its homeland is mostly a reflection of Japan's cultural and social conditions and particular school system. Experts unanimously agree that, as teaching is a complex social activity, adaptations to LS procedures will be necessary to fit local needs and contexts (STIGLER; HIEBERT, 2016; SCHIPPER et al., 2019). Pursuing this understanding, the above analysis reveals several aspects that should be taken into consideration for the effective implementation of LS outside Japan.

\section{Time Constraints}

Lack of shared time for the team to collaboratively conduct all the necessary activities to develop the LS model properly may simply refrain the implementation of this approach from the start. LS demands teachers' involvement (LIM-RATNAM et al., 2019) and, not surprisingly, more time of lesson planning than an ordinary class preparation (CERBIN; KOPP, 2006). "Protect their time", advices Dudley (2011, p. 7). Or how else can teachers be highly committed to the improvement of their own professional development if they are required to stay a hundred per cent of their working hours teaching? How can they volunteer if they need to cope with 2 or 3 jobs and work 10 hours a day to 
increase their income and make ends meet every month? The factor time seems to be a key component to be discussed and overcome if LS is to be sustained.

\section{Financial Support}

Connected to the issue mentioned above, providing financial supports for teachers and research projects is crucial to enable the implementation and sustainability of this approach. Takahashi and McDougal (2016) confirm that the provision of adequate time for teachers to participate in the LS model through the use of funds is an important catalyst of LS implementation. Even when funding is not allocated officially, it is raised through other avenues in order to guarantee this approach to be developed and spread (see, for example, LEWIS; PERRY; HURD, 2009).

\section{Search for Quick Results}

A quick result-oriented culture might not welcome LS practices as easily as they seek for better examining results to happen overnight (CAJKLER et al., 2015). In the LS movement, long-term goals are aligned with teachers' daily practice to build strong collaboration and shared results. Therefore, rushing the process will not bring the expected results. In this sense, Stigler and Hiebert (2016) point out the reason why LS might not work in the North American context: "we underestimate the time and effort it will take to actually implement the idea in an effective way" (p. 586). In the present review article, the authors claim that these reasons identified by Stigler and Hiebert are the highest challenges that countries new to LS face in getting funding and collaboration from teachers, organizations and public policies.

\section{Choice for a Suitable Learning/Teaching Theory}

This study has revealed that LS has been investigated alongside a variety of learning and teaching theories. This result might be related to the fact that LS is a flexible approach (SCHIPPER $e t$ al., 2020) and, as indicated by Norwich (2018), LS and LS-related practices might be developed by adopting aspects from different traditions. What is essential, however, is that Japanese scholars make this model more explicit to the international academy (SAITO, 2012) so that educators can choose an adequate theory to support their investigation in their local contexts. The question raised by Wood (2020, p. 98) as to "what is the learning theory that underpins JLS" (Japanese Lesson Study) might progress to "what are the adequate theories of learning that underpin LS?"

\section{Inclusion of Knowledgeable Others}

The inclusion of knowledgeable others to the LS model has been acknowledged as beneficial to all contexts, particularly the ones anew to this process. While examining the projects that emerged in North American settings, Takahashi and McDougal (2016) considered that knowledgeable others contributions are essential to effective LS development not only during the post-lesson discussion and but also during the planning process. In addition, the authors argued that, ideally, two different knowledgeable others should perform in each phase. In one respect, it is argued that the expertise of a knowledgeable other is not acquired through formal training, rather, it is developed through the participation in LS activities with colleagues and observation of a great number of final comments being given by peers and experts (Takahashi, 2014). In settings where LS is not a common practice, the author recognizes that opportunities to develop due expertise are rare, however contributions from knowledgeable others are even more necessary in these settings. In order to provide insight to the theme, Takahashi provides three steps that an inexperienced knowledgeable other might follow in order to ensure effective final comments. What is agreed unanimously is that research teams new to LS must not underestimate the importance of these professionals, in addition, researchers and organizations should collaborate to provide means for them to learn and develop this ability. 
RQ3. What lessons inform future researches or projects as to the necessary adaptations that should be made in order to develop a successful LS model?

Experts from Japan and China are becoming "more explicit about the theory behind lesson study, with respect to both its goals and the methods for achieving them" (STIGLER; HIEBERT, 2016, p. 582). This is an increasing demand from foreign researchers who are focusing on understanding how LS occurs in its natural environment, so that they can adapt it from there. The good news is that LS process may not be intended to be used the same way everywhere. In fact, it expected that LS differs across contexts (LEWIS; PERRY; MURATA, 2006).

This study provides evidence that LS has been implemented around the globe and producing many positive results. It has demonstrated a varied of characteristics in the procedures that resulted in benefits for the students, teachers and other stakeholders involved in the LS process. Such a flexible model permitted the adoption of a varied number of theories that sought to investigate the effects of LS across different subjects and school levels. It was also demonstrated that researchers are using different strategies and characteristics of LS in order to suit the local needs and necessities.

In summary, observing and being faithful to the core aspects of LS is essential if it is to be implemented as such. However, the findings in this study reveal that a number of negotiable procedures can be reviewed to contexts beyond Japan in order to make it viable. It might have come the moment each cultural setting will have to decide which non-defining aspects will have to be revised and how LS will best suit their needs and conditions. What is certain, though, is that there are no shortcuts if we intend to point out a way to transform the education system on individual, regional, national or global levels.

\section{CONCLUSION}

It was through writing this paper that the authors have reconsidered what they believed was the heart of LS, that is, the research lesson to be crafted and executed by the LS team. Rather, LS refers to a cultural process originated in Japan which is intrinsically connected to its people and traditions. As such, LS is encrusted in meta-aspects. It does not bear or stand out in a certain phase or activity, nor is it a matter of carrying out activities (LEWIS; PERRY; HURD, 2004). As Fujii (2014, p. 15) states, the heart of LS "is the educational value located at the meta-level." In other words, LS is developed through routines, practices and a lifelong and organically organized period of time, in which novices and experienced teachers jointly focus on student learning to answer "how-questions" over "what-ones". It is not intended to be commercially traded as a product to be used during a particular period of time, or simply shared through a PowerPoint presentation, as if the audience would automatically integrate it to their pedagogical practice.

As Professor Peter Dudley fortunately told the first author during the WALS2020 conference when questioned about what a researcher beginning to LS should do in order to introduce it successfully: "Give it a go!", he clarified. He was saying, live it! It is obvious that the visible processes for implementing LS are being more and more established by empirical researches and theoretical writings, and these are to be meticulously observed. However, beyond theory and procedures, LS is to be experienced. It has to be embraced sustainably. It has to be lived.

This study was motivated by the desire of encouraging more researchers, especially in Latin America, to introduce LS to their contexts, and learn from this study not only about the specific procedures that typically involve the LS movement, but also become aware of the potential and constraints of this professional development model. Firstly, in this respect, as South America was represented by only one research in this systematic review, it is suggested that future research identify and analyze how LS could be properly "translated" in this region, what educational and cultural values could contribute or hinder its use so that LS finds its own path of implementation in this context.

Secondly, further study is needed to investigate whether and how schools participating in LS projects continued implementing more LS activities some years after their first experience and how much LS has impacted teachers' and students' learning in contexts that have no tradition in this approach. Thirdly, while implementing the LS model, researchers should center their investigation on 
what students have to say about their own learning path through a constructionist, contextualized and meaningful environment, as discussed by Schlünzen et al. (2020), who defend the engagement of every member of the teaching community toward a more deeply, reflective, and inclusive school.

Results of this study should be interpreted in light of some limitations. This is a small-scale investigation which used a limited number of databases. It is likely that if more databases had been included, results would have been more robust. In addition, this study selected full-text publications. If more studies had allowed access to their full texts, discussions might have pointed to or included a different direction.

\section{ACKNOWLEDGEMENT}

This research was funded through the Coordination for the Improvement of Higher Education Personnel (CAPES) - Brazil.

\section{REFERENCES}

ALAMRI, N. M. The implementation of the Lesson Study strategy in teaching mathematics: teachers perspectives. Educational Research International, v. 5, p. 1-8, 2020. DOI: 10.1155/2020/1683758

BARBER, K. Developing teachers' mathematical-task knowledge and practice through lesson study. International Journal for Lesson and Learning Studies, v. 7, n. 2, p. 136-149, 2018. DOI: 10.1108/IJLLS-09-2017-0042

BAUMFIELD, V. et al. How lesson study is used in initial teacher education: an international review of literature. 2020. Manuscript submitted for publication.

BOCALA, C. From experience to Expertise: the development of teachers' learning in lesson study. Journal of Teacher Education, v. 66, n. 4, p. 349-362, 2015.

BRADSHAW, Z.; HAZELL, A. Developing problem-solving skills in mathematics: a lesson study. International Journal for Lesson and Learning Studies, v. 6, n. 1, p. 32-44, 2016. DOI: 10.1108/IJLLS-09-2016-0032

BROWN, C.; TAYLOR, C. Using design-based research to improve the lesson study approach to professional development in Camden (London). London Review of Education, v. 14, n. 2, p. 4-24, 2016. DOI: 10.18546/LRE.14.2.02

BUSSI, M. G. B. et al. Cultural transposition of Chinese lesson study to Italy. International Journal for Lesson and Learning Studies, v. 6, n. 4, p. 380-395, 2017. DOI: 10.1108/IJLLS-12-2016-0057

CAJKLER, W. et al. Lesson Study: towards a collaborative approach to learning in Initial Teacher Education? Cambridge Journal of Education, v. 43, n. 4, p. 537-554, 2013. DOI: 10.1080/0305764X.2013.834037

CAJKLER, W. et al. Teacher perspectives about lesson study in secondary school departments: a collaborative vehicle for professional learning and practice development, Research Papers in Education, v. 30, n. 2, p. 192-213, 2015. DOI: 10.1080/02671522.2014.887139

CALVO, A.; BLANCO, G. M. B.; FUEYO, A. The potential of lesson study Project as a tool for dealing with dilemmas in university teaching. International Journal for Lesson and Learning Studies, v. 7, n. 2, p. 124-135, 2018. DOI: 10.1108/IJLLS-12-2017-0056

CERBIN, W.; KOPP, B. Lesson study as a model for building pedagogical knowledge and improving teaching. International Journal of Teaching and Learning in Higher Education, v. 18, n. 3, p. 
250-257, 2006. Disponível em: <http://www.isetl.org/ijtlhe/pdf/IJTLHE110.pdf>. Acesso em: 10 out. 2020.

DANDAY, B. A.; MONTEROLA, S. L. C. Effects of microteaching multiple-representation physics lesson study on pre-service teachers' critical thinking. Journal of Baltic Science Education, v. 18, n. 5, p. 692-707, 2019. DOI: $10.33225 /$ jbse/19.18.692

DUDLEY, P. Lesson study: a handbook, 2011. Disponível em: <http://lessonstudy.co.uk/wpcontent/uploads/2012/03/Lesson_Study_Handbook_-_011011-1.pdf.> Acesso em 10 set. 2020.

DUDLEY, P. Teacher learning in Lesson Study: What interaction-level discourse analysis revealed about how teachers utilised imagination, tacit knowledge of teaching and fresh evidence of pupils learning, to develop practice knowledge and so enhance their pupils' learning. Teaching and Teacher Education, v. 34, p. 107-121, 2013. DOI: 10.1016/j.tate.2013.04.006

DUDLEY, P. Lesson study: a handbook. 2014. Disponível em: <http://lessonstudy.co.uk/wpcontent/uploads/2012/03/new-handbook-revisedMay14.pdf $>$ Acesso em 05 set. 2020.

DUDLEY, P. et al. Empirical evidence of the impact of lesson study on students' achievement, teachers' professional learning and on institutional and system evolution. Eur J Educ., v. 54, p. 202 217, 2019. DOI: $10.1111 /$ ejed.12337

ELLIOTT, J. Editorial review: Significant themes in developing the theory and practice of lesson study. International Journal for Lesson and Learning Studies, v. 5, n. 4, p. 274-280, 2016. DOI: 10.1108/IJLLS-08-2016-0022

ELLIOTT, J. What is lesson study? European Journal of Education, n. 54, p. 175-188, 2019. DOI: 10.1111/ejed.12339

FANG, Y.; WANG, H. Trends of and implications for the diffusion of lesson study: thematic analysis of WALS2019 conference presentations. International Journal for Lesson and Learning Studies, v. 10, n. 1, p. 61-74, 2021. DOI: 10.1108/IJLLS-09-2020-0063

FERNÁNDEZ, M. L. Learning through microteaching lesson study in teacher preparation. Action in Teacher Education, n. 26, p. 37-47, 2005. DOI: 10.1080/01626620.2005.10463341

FERNÁNDEZ, M. L. Investigating how and what prospective teachers mearn through lesson study. Teaching and Teacher Education, 26, p. 351-362, 2010. Disponível em:

$<$ www.elsevier.com/locate/tate>. Acesso em: 05 ago. 2020.

FUJII, T. Implementing Japanese lesson study in foreign countries: misconceptions revealed.

Mathematics Teacher Education and Development, v. 16, n. 1, p. 2-18., 2014. Disponível em: $<$ https://eric.ed.gov/?id=EJ1046666>. Acesso em 02 ago. 2020.

FUJII, T. Designing and adapting tasks in lesson planning: a critical process of Lesson Study. ZDM Mathematics Education, v. 48, p. 411-423, 2016. DOI 10.1007/s11858-016-0770-3

GRIFFITHS, J. Bridging the school placement gap with peer micro-teaching lesson study. International Journal for Lesson and Learning Studies, v. 5, n. 3, p. 227-238, 2016. DOI: 10.1108/IJLLS-11-2015-0035

GOUGH, D.; THOMAS, J.; OLIVER, S. Clarifying differences between review designs and methods. Systematic Reviews, v. 1, n. 28, p. 1-9, 2012. DOI: 10.1186/2046-4053-1-28 
GROVES, S.; DOIG, B. Adapting and implementing Japanese lesson study: some affordances and constraints. In: EAST ASIA REGIONAL CONFERENCE ON MATHEMATICS EDUCATION, 5, 2010, Tóquio. Anais eletrônicos... Tóquio: Society of Mathematical Education (JSME) In Search of Excellence of Mathematics Education, p. 699-706. 2010. Disponível em:

$<$ https://www.semanticscholar.org/paper/Adapting-and-implementing-Japanese-lesson-study- $\% 3 \mathrm{~A}$ Groves-Doig/2d3123b385d83b67298790604b0953d7e4f8e606\#citing-papers>. Acesso em: 10 ago. 2020.

HART, L. A study of Japanese lesson study with third grade mathematics teachers in a small school district. SRATE Journal, v. 17, n. 1, p. 32-43, p. 2009. Disponível em:

<https://files.eric.ed.gov/fulltext/EJ948667.pdf>. Acesso em: 10 ago. 2020.

HUANG, R. et al. Improving mathematics teaching as deliberate practice through Chinese lesson study. The Mathematics Educator, v. 26, n. 1, p. 32-55, 2017. Disponível em: $<$ https://eric.ed.gov/?id=EJ1153298>. Acesso em: 10

KANELLOPOULOU, E. D.; DARRA, M. Benefits, difficulties and conditions of lesson study implementation in basic teacher education: a review. International Journal of Higher Education, v. 8, n. 4, p. 18-35, 2019. DOI: 10.5430/ijhe.v8n4p18

KHOKHOTVA, O.; ALBIZURI, I. E. Student voice in Lesson Study as a space for EFL teachers' learning: a case study in Kazakhstan. International Journal for Lesson and Learning Studies, v. 9, n. 2, p. 153-166, 2020. DOI: 10.1108/IJLLS-06-2019-0054

KLAMMER, S.; HANFSTINGL, B. A first time lesson study that turned into a learning study. International Journal for Lesson and Learning Studies, v. 8, n. 4, p. 305-319, 2019. DOI: 10.1108/IJLLS-04-2019-0029

KLEFBECK, K. Lesson study for students with intellectual disability. International Journal for Lesson and Learning Studies, v. 9, n. 3, p. 245-259, 2020. DOI: 10.1108/IJLLS-12-2019-0082

KOTELAWALA, U. Lesson study in a methods course: connecting teacher education to the field. The Teacher Educator, v. 47, p. 67-89, 2012. DOI: 10.1080/08878730.2012.633840

LAMB, P. Peer-teaching between pre-service teachers: embracing Lesson Study. International Journal for Lesson and Learning Studies, v. 4, n. 4, p. 343-361, 2015. DOI: 10.1108/IJLLS-03-2015-0012

LEIFLER, E. Teachers' capacity to create inclusive learning environments. International Journal for Lesson and Learning Studies, v. 9, n. 3, p. 221-244, 2020. DOI 10.1108/IJLLS-01-2020-0003

LEWIS, C. Lesson study: the core of Japanese professional development. In: AMERICAN EDUCATIONAL RESEARCH ASSOCIATION MEETINGS, 2000. Anais... New Orleans, 2000. p. 1-48. Disponível em:

$<$ https://eric.ed.gov/?q=Lesson + Study $\% 3 \mathrm{a}+$ The + Core + of + Japanese + Professional+Development.\& id=ED444972>. Acesso em: 02 ago. 2020.

LEWIS, C. Lesson study: a handbook for teacher-led improvement of instruction. Philadelphia: Research for Better Schools, 2002.

LEWIS, C. What is the nature of knowledge development in lesson study? Educational Action Research, v. 17, n. 1, p. 95-110, 2009. DOI: 10.1080/09650790802667477

LEWIS, C. et al. Lesson Study Comes of Age in North America. Phi Delta Kappan Magazine, v. 88, p. 273-281, 2006. Disponível em: 
<https://journals.sagepub.com/doi/abs/10.1177/003172170608800406?journalCode=pdka >. Acesso em 15 set. 2020.

LEWIS, C.; PERRY, R. Lesson study with mathematical resources: a sustainable model for locally-led teachers professional learning. Mathematics Teacher Education and Development, v. 16, n. 1, p. 1 20 , 2014. Disponível em: <https:// files.eric.ed.gov/fulltext/EJ1046670.pdf.> Acesso em: 12 set. 2020.

LEWIS, C.; PERRY, R.; HURD, J. A Deeper Look at Lesson Study. Educational Leadership, v. 61, n. 5, p. 18-22, 2004. Disponível em:

<http://tccore2015.weebly.com/uploads/2/8/7/3/28734887/deeperlookatls-2.pdf>. Acesso em 15 set. 2020 .

LEWIS, C.; PERRY, R.; HURD, J. Improving mathematics instruction through lesson study: a theoretical model and North American case. Journal of Mathematics Teacher Education, v. 12, p. 285-304, 2009. DOI: 10.1007/s10857-009-9102-7

LEWIS, C.; PERRY, R.; MURATA, A. How should research contribute to instructional improvement? The case of lesson study. Educational Researcher, v. 35, n. 3, p. 3-14, 2006.

LIM-RATNAM, C. T. et al. Lost in adaptation? Issues of adapting lesson study in non-Japanese contexts. Educational Research for Policy and Practice, v. 18, p. 263-278, 2019. DOI: https://doi.org/10.1007/s10671-019-09247-4

LOMIBAO, L. S. Enhancing mathematics teachers' quality through Lesson Study. SringerPlus, v. 5, n. 1, p. 1-13, 2016. DOI: $10.1186 /$ s40064-016-3215-0

LUCENARIO, J. L. S. et al. Pedagogical content knowledge-guided lesson study: effects on teacher competence and students' achievement in chemistry. Education Research International, v. 3, p. 1-9, 2016. Disponível em: <http://dx.doi.org/10.1155/2016/6068930>. Acesso em 10 out. 2020.

MEWALD, C.; MÜRWALD-SCHEIFINGER, E. Lesson study in teacher development: a paradigm shift from a culture of receiving to a culture of acting and reflecting. European Journal of Education, v. 54, p. 218-232, 2019. DOI: 10.1111/ejed.12335

MON, C. C. ; DALI, M. H. ; SAM, L. C. Implementation of lesson study as an innovative professional development model among Malaysian school teachers. Malaysian Journal of Learning and

Instruction, v. 13, p. 83-111, 2016. Disponível em:

$<$ https://files.eric.ed.gov/fulltext/EJ1134522.pdf>. Acesso em 10 set. 2020.

MOHER, D. et al. Preferred reporting items for systematic reviews and meta-analyses: the PRISMA statement. PLoS Med, v. 6, n. 7, 2009. DOI: 10.1371/journal.pmed1000097

MOHER, D. et al. Preferred reporting items for systematic review and meta-analysis protocols (PRISMA-P) 2015 statement. Systematic Reviews, v.4, n.1, 2015. Disponível em:

<http://www.systematicreviewsjournal.com/content/4/1/1>. Aceesso em 07 jul. 2020.

MOSTOFO, J. The impact of using lesson study with pre-service mathematics teachers. Journal of Instruction Research, v. 3, p. 55-63, 2014. Disponível em:

<https://files.eric.ed.gov/fulltext/EJ1127641.pdf>. Acesso em: 12 set. 2020.

NORWICH, B. Making sense of international variations in lesson study and lesson study-like practices: An exploratory and conceptual perspective. International Journal for Lesson and Learning Studies, v. 7, n. 3, p. 201-216, 2018. Disponível em: <https://doi.org/10.1108/IJLLS-02-2018-0007>. Acesso em: 02 set. 2020 . 
OLFOS, R.; ISODA, M.; ESTRELLA, S. Más de una década de Estudio de Clases en Chile: hallazgos y avances. Revista Pardigma, v. 41, p. 190-221, 2020.

PONTE, J. P. et al. O estudo de aula como processo de desenvolvimento profissional de professores de matemática. Bolema, v. 30, n. 56, p. 868- 891, 2016. DOI: http://dx.doi.org/10.1590/1980-

$4415 \mathrm{v} 30 \mathrm{n} 56 \mathrm{a} 01$

RAMOS-RODRÍGUEZ, E.; MARTÍNEZ, P. L.; PONTE, J. P. Práctica y reflexión de profesores de matemáticas chilenos bajo la perspectiva del estudio de clases. Quadrante, v. 26, n. 2, p. 69-97, 2017. DOI: https://doi.org/10.48489/quadrante.22950

SÁNCHEZ, E. A. S.; GÓMEZ-BLANCARTE, A. L. La negociación de significado como proceso de aprendizaje: el caso de un programa de desarrollo profesional en la enseñanza de la estadística.

Revista Latinoamericana de Investigación en Matemática Educativa, v. 18, n. 3, p. 387-419, 2015. DOI: $10.12802 /$ relime.13.1834

SAUNDERS, W. M.; GOLDENBERG, C. N.; GALLIMORE, R. Increasing achievement by focusing grade-level teams on improving classroom learning: A prospective, quasi-experimental study of title 1 schools. American Educational Research Journal, v. 46, n. 4, p. 1006-1033, 2009. DOI:

10.3102/0002831209333185

SAITO, E. Key issues of lesson study in Japan and the United States: a literature review, Professional Development in Education, v. 38, n. 5, p. 777-789, 2012. Disponível em:

<http://dx.doi.org/10.1080/19415257.2012.668857>. Acesso em: 10 out. 2020.

SCHIPPER, T. M, GOI et al. Lesson Study in Dutch initial teacher education explored: its potential and pitfall. International Journal for Lesson and Learning Studies, v. 9, n. 4, 351-365, 2020.

DOI: https://doi.org/10.1108/IJLLS-04-2020-0018

SCHLÜNZEN, E. T. M. et al. Abordagem Construcionista, Contextualizada e Significativa: Formação, Extensão e Pesquisa no Processo de Inclusão. Curitiba: Editora Appris, 2020.

SHUILLEABHAIN, A. N. Developing mathematics teachers' pedagogical content knowledge in lesson study. International Journal for Lesson and Learning Studies, v. 5, n. 3, p. 212-226, 2016. DOI: 10.1108/IJLLS-11-2015-0036

SEINO, T.; FOSTER, C. Analysis of the final comments provided by a knowledgeable other in lesson study. Journal of Mathematics Teacher Education, v. 48, 2020. DOI: 10.1007/s10857-020-09468-y

SOTO, M. et al. Bridging distances: professional development for higher education faculty through technology-facilitated lesson study. Journal of University Teaching \& Learning Practice, v. 16, n. 3, p. 1-19, 2019. Disponível em:

<https://ro.uow.edu.au/cgi/viewcontent.cgi?article=1893\&context=jutlp>. Acesso em 10 out. 2020.

STIGLER. J. W.; HIEBERT, J. Lesson study, improvement, and the importing of cultural routines. ZDM Mathematics Education, v. 48, p. 581-587, 2016. DOI 10.1007/s11858-016-0787-7

SUH, J. M.; FULGINITI, K. "Situating the learning" of teaching: implementing lesson study at a professional development school. School-University Partnerships, v. 5, n. 2, p. 24-37, 2012.

TAKAHASHI, A. The role of the Knowledgeable other in lesson study: examining the final comments of experiences lesson study practitioners. Mathematics Teacher Education and Development, v. 16, n. 1, p. 1-17, 2014. Disponível em: < https:// files.eric.ed.gov/fulltext/EJ1046714.pdf>. Acesso em: 09out. 2014. 
TAKAHASHI, A.; MCDOUGAL, T. Collaborative lesson research: maximizing the impact of lesson study. ZDM Mathematics Education, v. 48, p. 513-526, 2016. Disponível em:

<https://doi.org/10.1007/s11858-015-0752-x>. Acesso em: 05 set. 2020.

TAMURA. T.; UESUGI, Y. Involving students in lesson study: a new perspective. International Journal for Lesson and Learning Studies, v. 9, n. 2, p. 139-151, 2020. DOI: 10.1108/IJLLS-042018-0026

THINWIANGTHONG, S.; EDDY, C. M.; INPRASITHA, M. Mathematics teachers' abilities in developing formative assessment after the introduction of lesson study and open approach innovations. Malaysian Journal of Learning and Instruction, v. 17, n. 1, p. 111-132, 2020. Disponível em: <https:// files.eric.ed.gov/fulltext/EJ1248853.pdf>. Acesso em 05 set. 2020.

VERMUNT, J. D. et al. The impact of Lesson Study professional development on the quality of teacher learning. Teaching and Teacher Education, v. 81, n. 1, p. 61-73,

2019. DOI: $10.1016 /$ j.tate.2019.02.009

WOOD, K. The path of teachers' learning through lesson and learning studies. International Journal for Lesson and Learning Studies, v. 9, n. 2, p. 93-99, 2020. DOI: 10.1108/IJLLS-12-2019-0083

WOOD, K.; CAJKLER, W. A participatory approach to Lesson Study in higher education.

International Journal for Lesson and Learning Studies, v. 5 n. 1, p. 4-18, 2016. DOI: 10.1108/IJLLS-08-2015-0027

YENMEZ, A. A. et al. Evolution of mathematics teachers' pedagogical knowledge when they are teaching through modeling. International Journal of Education in Mathematics, Science and Technology (IJEMST), v. 5, n. 4, p. 317-332, 2017. DOI:10.18404/ijemst.296552

YILDIZ, A.; BALTACI, S. Reflections from the lesson study for the development of technopedagogical competences in teaching fractal geometry. European Journal of Educational Research, v. 6, n. 1, p. 41-50, 2017. DOI: 10.12973/eu-jer.6.1.41

YOSHIDA, M. Lesson study: a case of a Japanese approach to improving instruction through schoolbased teacher development. 1999. 528 f. Tese (Doutorado em Educação) - University of Chicago, Chicago, 1999.

ZHOU, G.; XU, J. Microteaching lesson study: an approach to prepare teacher candidates to teach science through inquiry. International Journal of Education in Mathematics, Science and Technology, v. 6, n. 3, p. 235-247, 2017. DOI: 10.18404/ijemst.296039.

\section{DECLARATION OF CONFLICTING INTERESTS}

The authors declare that there is no conflict of interest. 